\title{
PREDSTAVA O SEBI IN NAČRTOVANIE KARIERE
}

mag. Daniela

Brečko

GV Izabraževanje

Model kariernih sider kot vodilo za načrtovanje osebne kariere in vodnik organizacijam
za oblikovanje psihološke pogodbe

$\mathbf{K}$ znanje, ki si ga je posameznik pridobil med šolanjem, je najbrž edini možni odgovor: tisti, ki so zadovoljni s svojo izbiro poklica. Le zadovoljni posamezniki lahko namreč $\mathrm{v}$ celoti uporabijo svoje znanje in sposobnosti. Individualne razlike sicer lahko določajo izbiro poklicne poti, vendar ne nujno. Morda se je nekdo za določeno poklicno pot odločil po volji staršev, prijateljev, vrstnikov ... in šele ko vstopi v svet dela, zasede določeno delovno mesto, spozna, da to ni bila njegova izbira.

Poklicna izbira je zelo povezana s posameznikovo samopodobo, ki nastane na podlagi delovnih izkušenj, to je uspehov, samovrednotenja, povratnih informacij. Hkrati z razvojem kariere namreč poteka tudi razvoj samopodobe posameznika, ki zajema odgovore na nekaj temeljnih vprašanj:

1. Kakšne so moje sposobnosti, nadarjenost? Kje so moje prednosti in kje slabosti?

2. Kaj so moji glavni motivi, kakšne so moje potrebe, cilji in ambicije? Kaj želim in česa ne maram, bodisi da tega nisem nikoli maral bodisi da sem dosegel določeno stopnjo vpogleda in tega ne maram več?

3. Kakšne so moje vrednote, katera so najpomembnejša merila, po katerih presojam, kaj in kako delujem? Ali delam to, kar je skladno z mojimi vrednotami? Kako se po- čutim pri tem, kar delam? Sem ponosen na svoje delo in kariero ali se ju sramujem?

Ta predstava se razvije iz pogledov o sebi, ki jih je posameznik imel v mladosti in do konca formalnega izobraževanja. Vendar ta podoba ne more dozoreti, dokler nima dovolj poklicnih izkušenj, na podlagi katerih spozna lastne darove, motive in vrednote. Za takšno učenje je potrebnih deset let konkretnih delovnih izkušenj ali več. Če ima posameznik veliko različnih izkušenj in za vsako obdobje pomenljive povratne informacije, se predstava o sebi razvija hitreje. Če pa v prvih letih kariere spozna malo delovnih mest ali dobi pičle povratne informacije, lahko traja ta proces precej dlje.

Darovi, motivi in vrednote se prepletajo. Posameznik se nauči biti boljši na področjih, ki jih ceni; z zadevami, ki jih že tako dobro opravlja, se rad ukvarja, se jih nauči ceniti in motivirati z njimi. Postopoma se tudi nauči, da se izogiba tistih zadev, ki jih ne opravlja dobro, čeprav se brez jasne povratne informacije nemara oklepa iluzij o sebi, zaradi katerih mu še večkrat spodleti. Darovi brez motivacije postopoma zakrnijo. In nasprotno: ob novih izzivih se lahko pokažejo pritajeni ali skriti darovi, ki se prej niso mogli razviti in pokazati. 
Ljudje se razlikujejo glede na to, ali darovi, motivi ali vrednote že od začetka prevladujejo $v$ njihovi predstavi o sebi in tako postanejo osrednja tema $v$ njihovi karieri. Sčasoma pa jih potreba po raynovesju prisili, da iščejo skladnost in povezavo med različnimi elementi predstave o sebi. Kako se naučimo te skladnosti? Ljudje vstopijo v svet dela z mnogimi ambicijami, upi, strahovi in iluzijami, a s sorazmerno skopim poznavanjem samega sebe, še posebno svojih sposobnosti in darov. $\mathrm{S}$ preskusi in svetovanjem dobijo okvirne Delovne izkušnje in povratne informacije o delu vplivajo na predstavo $o$ sebi. informacije o svojih zanimanjih, motivih, vrednotah in tudi intelektualnih ter motoričnih sposobnostih, ne morejo pa v resnici določiti, kako dobri bodo pri določeni vrsti dela ali kako se bodo čustveno odzivali nanj.

To velja še najbolj za vodstvene kadre, ker je težko motivirati nekatere ključne spretnosti in zmožnosti na tem področju. Dokler posameznik resnično ne začuti odgovornosti pri tem, ko zaupa velike vsote denarja, sprejema ljudi $v$ službo in jih odpušča, zavrne podrejenega, ki ga ceni, ne more vedeti, ali bo to lahko delal in ali mu bo sploh všeč. To načelo velja še za mnoga druga delovna mesta: posameznik ne more vedeti, ali je nadarjen za določeno delo in ali mu ugaja, ne da bi ga dejansko opravljal.

\section{"ŠOK REALNOSTI《}

Prva leta, ki jih prebijemo v poklicu, so obdobje, ki je bistveno za učenje - učenje o poklicu ali organizaciji, pa tudi o svojem odnosu do zahtev delovnega mesta. Ta proces je pogosto boleč in poln presenečenj, saj je značilno, da začnemo prvo službo $z$ napačnimi predstavami in iluzijami. Predstave o tem, kakšni smo in kakšno bo naše delo, so velikokrat čisto drugačne od izkušenj, ki jih dobimo pri delu; doživimo tako imenovani šok real- nosti - pojav, ki ga je mogoče opaziti pri začetnikih v kateremkoli poklicu.

Ko si nabiramo delovne izkušnje, imamo možnost, da izbiramo; pri teh odločitvah šele začnemo preverjati, kaj se nam zdi resnično pomembno. Na površje pridejo prevladujoča področja - kritične spretnosti ali zmožnosti, ki bi jih rad uporabljali, ali pa bistvene potrebe ali vrednote, ki prevladujejo v našem odnosu do življenja. Prej smo imeli nemara le nedoločen občutek za to, toda dokler ne dobimo stvarnih izkušenj, še ne vemo, kako pomembni so in kako se vsak dar, motiv ali vrednota v subjektivni hierarhiji povezuje $\mathrm{z}$ drugimi elementi osebnosti. Šele ko smo pred težavnimi odločitvami, začnemo izbirati tisto, kar je za nas zares pomembno.

S kopičenjem delovnih izkušenj in povrătnih informacij se marsikaj pojasni in izčisti, posameznik si pridobi vpogled, ki je podlaga za racionalnejše in tehtnejše odločitve $v$ zvezi s kariero. Predstava o sebi čedalje bolj funkcionira kot sistem, ki nas vodi, in sidro, ki omejuje izbire v zvezi s kariero. Človek začne dobivati občutek, kaj je »jaz« in kaj »ni jaz«. To spoznanje ga pravilno usmerja ali ostane vsaj $\mathrm{v}$ varnem pristanišču. Kadar ljudje pripovedujejo o svoji izbiri v karieri, se velikokrat spominjajo, kako so se vrnili k zadevam, od katerih so se že oddaljili, ali pa so ugotovili, kaj v resnici želijo početi, oziroma so se preprosto našli.

\section{KARIERNO SIDRO KOT PREDSTAVA O SEBI}

Karierno sidro, kot ga opredeljujemo v zvezi $\mathrm{s}$ tem, je tisti dejavnik v posameznikovi predstavi o sebi, ki se mu ne bo odrekel niti, ko bodo pred njim težavne odločitve. Značilno je, da nam uspe $v$ karieri zadovoljiti šroko paleto potreb, toda vse niso enako pomembne. Če ne moremo zadovoljiti vseh, je pomembno vedeti, katerim od njih bomo dali prednost. 
Karierno sidro se vedno ne ujema s poklicem, ki ga posameznik opravlja, zaradi zunanjih omejitev, na katere posameznik ne more vplivati. Gmotne razmere ali bolezen v družini mu recimo preprečijo, da bi uresničil to, kar mu narekuje njegova podoba o sebi. Med pogovorom tak posameznik pojasni, da to, kar zdaj dela, spravzaprav nisem jaz; to ni tisto, kar bi rad delal ali česar sem sposoben $\%$. To ni samo prazno govorjenje o iluzijah; pogosto posameznik udejanji predstavo o sebi, takoj ko zunanja omejitev izgine.

Zgled za karierno sidro je obubožan umetnik, ki vozi taksi. Predstava o sebi se spremeni, če si posameznik sistematično pridobiva izkušnje in povratne informacije, ki mu onemogočijo, da bi še naprej živel v oblakih - recimo umetnik, čigar umetnost ne dosega niti njegovih meril. Vendar je mogoče, da se posameznikova predstava o sebi ne spremeni, če se mu zdijo omejitve zgolj zunanje in prehodne.

Že na začetku kariere se vsakdo sreča z vprašanji, kako uskladiti delovne, družinske in osebne prioritete. Nekateri se odločijo, da bodo postavili delo na tretje mesto, ker je samo sredstvo za preživetje. Pri tem se izkušnja oblikuje predvsem s tistim, kar bi lahko imenovali »življenjsko sidro«, V prispevku se bomo najprej osredotočili na tiste posameznike, za katere sta delo in kariera toliko pomembna, da se bomo lahko pogovarjali o kariernih sidrih. Za mlajšse ljudi utegne biti pojem življenjskega sidra bolj smiseln, starejši pa bodo morda na novo ocenili zavezanost karieri in zmanjšali pomen svojega kariernega sidra.

\section{NASTANEK POJMA KARIERNO SIDRO}

Pojem karierno sidro izhaja iz študije, ki jo je E. Shein opravil, da bi dobili vpogled in bolje razumeli, kako se razvija kariera ljudi na vodilnih mestih in kako so se ti naučili vrednot in postopkov v organizacijah, $v$ katerih so bili zaposleni. Leta 1961 je začel longitudinalno raz-
Karierno sidro je predstava o sebi, ki je lahko izjemno trdna, čeprav posameznik nima možnosti, da bi jo uresničil.

iskavo, s katero je zajel štiriinštirideset absolventov magistrskega študija na Sloan School of Management. Začetne intervjuje in pregled vrednot ter stališč je izvedel v letih 1961, 1962 in 1963, ko so bili sodelujoči študentje drugega letnika vpisani v dveletni magistrski študij. $\mathrm{Z}$ njimi so imeli pogovore tudi na njihovih delovnih mestih šest mesecev po končanem študiju in znova eno leto po končanem študiju.

Udeleženci so izpolnili vprašalnike pet let po končanem študiju in imeli še pogovore leta 1973, kó so imeli za seboj že deset do dvanajst let službe. Tako so dobili raziskovalci vpogled $\mathrm{v}$ to, kako se je razvijala njihova kariera. $\mathrm{V}$ intervjujih leta 1973 so podrobno kronološko popisali dotedanjo kariero in našteli ne le kljuěne odločitve ter dogodke, temveč tudi premislili, zakaj so se tako odločili in kako so se počutili ob posamezni spremembi.

Pokazalo se je, da je bilo dogajanje v zgodovini kariere vsakega posameznika različno, toda razlogi za njihove odločitve in vzorec njihovih občutkov pri tem so bili presenetljivo podobni. Pri udeležencih so temeljne teme, ki se jih pogosto niso niti zavedali, odsevale vse močnejši občutek jaza, ki je izhajal iz tistega, česar so se naučili v prvih letih. Kadar so se preskusili na delovnih mestih, ki jim niso ustrezala, so navajali, kako jih je nekaj usmerilo nazaj $\mathrm{k}$ delu, pri katerem so se bolje počutili. Od tod izhaja tudi prispodoba sidra.

\section{TIPI KARIERNIH SIDER}

Na podlagi longitudinalne študije in pogovorov o zgodovini kariere več sto ljudi na različnih stopnjah kariere je Shein razvrstil sidra v osem kategorij:

- tehnično-funkcionalna sposobnost,

- managerska sposobnost, 
- samostojnost/neodvisnost,

- varnost/stabilnost,

- podjetniška ustvarjalnost,

- poslanstvo/predanost,

- čisti izziv,

- življenjski slog.

Pojem karierno sidro označuje področje, ki ima za posameznika tak pomen, da se mu ne bi nikakor odrekel. Posameznik si ustvari temeljno podobo o sebi $v$ skladu s to temo, ki postane najpomembnejši element na vsaki stopnji kariere.

Koncept, ki ga Shein ponuja v svojí raziskavi, lahko resnično služi kot model za načrtovanje osebne kariere, še posebej zato, ker se je izkazalo, da se dejansko ne spreminja radikalno. Torej bi lahko takrat, ko se odločamo za prvi poklic, lahko preverili svoje karirerno sidro in se na tej podlagi bolje odločili.

Da bi v celoti razumeli ta koncept, si moramo podrobneje ogledati posamezna sidra in osvetliti odgovore na vprašanje, kako se med seboj razlikujejo posamezniki z različnimi sidri. Opisi posameznih sider se začnejo s splošnimi značilnostmi sidra, nadaljujejo pa se z vprašanji, kako usmerjamo posamezne tipe, in predstavitvijo vrst dela, ki jih ima posamezen tip najraje.

\section{Tehnično-funkcionalna sposobnost}

Nekateri posamezniki ugotovijo, da imajo velik dar, obenem pa tudi močno motivacijo za določeno vrsto dela. Tisto, kar jim da pravi zagon, je udejanjanje tega daru in zadovoljstvo ob zavesti, da so izvedenci. To se lahko zgodi na kateremkoli delovnem področju. Inženir lahko recimo odkrije, da je zelo dober pri načrtovanju; trgovski potnik ugotovi, da tor proizvodnje občuti zadovoljstvo pri uprav-

ljanju kompleksnih obratov; finančni analitik odkrije svojo sposobnost za reševanje zapletenih problemov pri vlaganju kapitala in užitek pri tem; učiteljica se veseli vse obsežnejšega znanja, ki si ga pridobiva na svojem področju ...

Ko ti posamezniki napredujejo po poti kariere, ugotovijo, da so se znašli na drugih delovnih področjih, na katerih so manj zadovoljni in ki so jih manj vešči. Začutijo, da jih vleče nazaj na področja, na katerih so se počutili sposobni in zadovoljni. Začnejo se istovetiti z vsebino svojega dela, tehničnimi in funkcionalnimi področji, na katerih so uspešni, in tu izmojstrijo svoje spretnosti.

Posamezniki, ki so tehnično-funkcionalno zasidrani, se posvetijo specializaciji in podcenjujejo funkcijo generalnega managerja, čeprav so pripravljeni biti funkcionalni managerji, če jim to omogoča, da ostanejo v stiku s svojim strokovnim področjem. Čeprav je na začetku usmeritev večine karier tehničnofunkcionalna in je njihova zgodnja faza skoraj vedno povezana s specializacijo, slednja ne navdušuje vsakogar.

Vrsta dela. Najpomembnejša značilnost dela, ki si ga želijo pripadniki te skupine, je, da jim pomeni izziv. Če pri njem ne preskušajo

Za nekatere posameznike je specializirano delo predvsem sredstvo, s katerim postanejo člani đoločene organizacije ali pa pridobijo večjo varnost, manj pa v njem uživajo. Za druge je preprosto le prvi klin na hierarhični lestvici $v$ podjetju, korak na poti do vodilnih funkcij. Za tretje je priložnost, da se naučijo nekaterih spretnosti, ki jih bodo potrebovali za neodvisno ali podjetniško dejavnost. Iz tega torej lahko sklepamo, da sicer večina začenja na ozko specializiranih področjih, le nekaterim pa delo prinaša toliko notranjega zadovoljstva, da razvijejo karierno sidro na podlagi specializacije. 


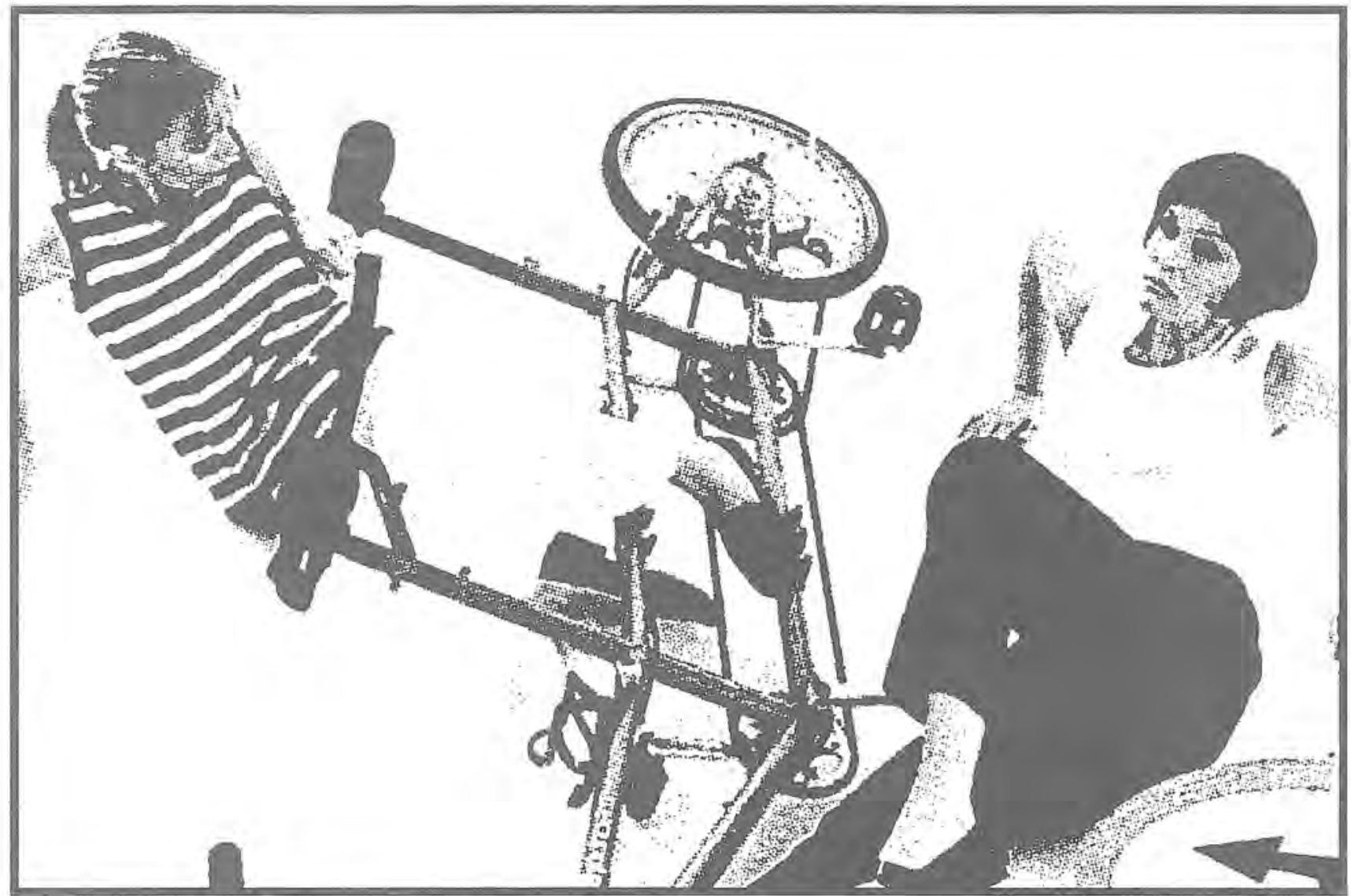

svojih zmožnosti in spretnosti, se jim kmalu zazdi dolgočasno in poniževalno, zato se začnejo ozirati po drugih nalogah. Njihov občutek lastne vrednosti je odvisen od tega, ali izkazujejo svojo nadarjenost, zato potrebujejo naloge, ki jim to omogočajo. Druge morda zanima kontekst dela, za to skupino pa je najbolj bistvena vsebina dela.

\section{Managerska sposobnost}

Nekateri posamezniki - toda samo nekateri med napredovanjem svoje kariere ugotovijo, da si resnično želijo postati managerji, da jih zanima vodenje kot tako, da imajo sposobnosti, ki jih mora imeti manager, in ambicije, da bi se dvignili na tisto raven organizacije, na kateri bodo odgovorni za najpomembnejše odločitve $v$ zvezi s politiko podjetja in bodo njihova prizadevanja začrtala mejo med uspehom in neuspehom.

Pripadniki te skupine se razlikujejo od tehnično-funkcionalnih tipov po tem, da vidijo specializacijo kot past. Razumejo, kako nujno je dobro poznavanje različnih področij, in sprejemajo dejstvo, da moraš biti izvedenec na svojem področju, če hočeš dobro funkcionirati kot manager. Ključne vrednote in motivi za to skupino ljudi so napredovanje do višjih ravni odgovornosti, možnosti za vodenje, prispevek $\mathrm{k}$ uspehu podjetja in visok dohodek.

Ko pridejo v organizacijo, si večina želi napredovati. Mnogi neposredno izražajo ambicije, da bi se povzpeli na vrh, le redki pa imajo realno predstavo o tem, kateri darovi, motivi in vrednote so potrebni, da se resnično povzpneš na vrh. Z izkušnjami postane zlasti 
tistim, ki so se zavezali karieri managerja, jasno, da potrebujejo za ta vzpon ne samo veliko motivacije, temveč tudi mešanico darov in spretnosti, pri tem predvsem izstopajo analitične sposobnosti, sposobnost medosebnega in medskupinskega sporazumevanja ter čustvena inteligentnost.

Vrsta dela. Managersko zasidrani ljudje si Želijo prevzeti veliko odgovornosti, imeti pestro, dopolnjujoče se delo, polno izzivov, možnosti za vodenje in priložnosti, da pripomorejo $\mathrm{k}$ uspehu svoje organizacije. Privlačnost svojega dela merijo po tem, kako pomembno je za uspeh organizacije, in se močno istovetijo z organizacijo, njenim uspehom ali neuspehom kot merilom, kako dobro opravljajo delo, V tem smislu so torej res »ljudje organizacije «, katerih istovetnost temelji na tem, da imajo možnost voditi uspešno podjetje.

\section{Samostojnost/neodvisnost}

Nekateri posamezniki že na začetnih stopnjah svoje kariere odkrijejo, da ne prenesejo omejitev, ki jim jih nalagajo pravila, postopki, delovni čas, predpisana oblačila in druge norme, ki so si jih zamislili drugi in ki se skoraj brez izjeme pojavljajo $\mathrm{v}$ vsaki organizaciji. Ne glede na svoje delovno področje imajo potrebo, da bi delali po svoje, v skladu s svojim tempom in svojimi merili. Čutijo, da jih življenje v organizaciji omejuje, da je iracionalno in da preveč posega $v$ njihovo zasebnost; zato se raje podajo na bolj neodvisno pot ka-

Vsakdo ima potrebo po določeni ravni samostojnosti, ki v različnih življenjskih obdobjih seveda niha. Za nekatere pa postane ta potreba ključna; čutijo, da morajo biti vedno kapitani ladje, na kateri plujejo. Včasih se skrajna potreba po neodvisnosti porodi iz visoke ravni izobrazbe in strokovnosti, ko se posameznik že med učnim procesom nauči, da se zanese samo nase in je $v$ celoti odgovoren zase. Včasih se takšni občutki razvijejo iz vzgojnih metod, ki so močno poudarjale samostojnost in neodvisno presojo. riere, vendar po njihovem okusu. Če morajo izbirati med trenutnim delom, ki dopušča samostojnost, in boljšim, pri katerem bi se morali tej samostojnosti odpovedati, tako zasidrani posamezniki raje obdržijo prvo.

Posamezniki, ki si začnejo organizirati kariero na podlagi takšnih potreb, se nagibajo $\mathrm{k}$ neodvisnim poklicem. Če jih zanima posel ali trženje, se morda usmerijo $\mathrm{v}$ svetovanje ali poučevanje. Ali pa se usmerijo na področja, na katerih je samostojnost sorazmerno velika celo $v$ velikih organizacijah - raziskave in razvoj, prodaja na terenu, obdelava podatkov, raziskave trga, finančne analize ali vodenje geografsko oddaljenih podružnic.

Vrsta dela. Posameznik, zasidran v samostojnosti, ima najraje jasnó opisano, časovno določeno delo na svojem strokovnem področju. Sprejemljivo in pogosto tudi zaželeno je pogodbeno ali projektno delo, bodisi za polovični ali polni delovni čas bodisi celo občasno. Poleg tega si želi delo, pri katerem so cilji jasno določeni, sredstva in poti pa si lahko izbere sam. Ne prenese, da mu nadrejeni »diha za ovratnik«; lahko se strinja s cilji, ki jih določi organizacija, vendar hoče potem imeti mir.

\section{Varnost/stabilnost}

Pri nekaterih ljudeh prevladuje potreba po takšni karieri, ki bi jim omogočila, da bi se počutili varne in mirne, da bi lahko predvideli dogodke in se sprostili ob spoznanju, da so uspešni. Vsakdo potrebuje določeno stopnjo varnosti in stalnosti; v določenih življenjskih obdobjih postane kljuěno vprašanje finančna varnost, recimo kadar vzgajamo in šolamo otroke ali kadar se približujemo upokojitvi. Za nekatere pa je to področje najpomembnejše y vsej njihovi karieri - tako pomembno, da ta dejavnik vodi in omejuje vse večje odločitve y zvezi s kariero.

Taki posamezniki velikokrat iščejo službo $\mathrm{v}$ 
organizacijah, ki zagotavljajo trajanje delovnega razmerja, imajo ugled, se izogibajo odpuščanju ljudi, imajo dobre pokojninske sheme in programe ugodnosti ter slovijo po tem, da so močne in zanesljive, Zaradi tega razloga so zanje pogosto privlačne službe $\mathrm{v}$ vladi in državni upravi. Nekaj zadovoljstva jim prinese tudi istovetenje $\mathrm{z}$ organizacijo, čeprav nimajo visokega ali pomembnega položaja.

Posamezniki, ki so zasidrani v varnosti in stabilnosti, imajo radi »zlate lisice« in so ponavadi pripravljeni predati odgovornost za upravljanje njihove kariere svojim delodajalcem. V zameno za trajanje delovnega razmerja so pripravljeni, da jim drugi določajo, kaj naj delajo, koliko naj potujejo, kje naj živijo in kako pogosto naj zamenjajo delovno mesto. Zato se včasih zdi, da so premalo ambiciozni, ali pa so deležni zaničevanja v krogih, ki cenijo predvsem ambicije in dosežke. To je lahko neupravičeno, saj so se nekateri med njimi napredovali $z$ zelo skromnih začetkov na visoke vodstvene položaje. Kadar dosežejo raven srednjega vodstva $v$ velikih organizacijah, čutijo, da jim je uspelo glede na to, kje so začeli v socialno-ekonomskem pogledu.

Vrsta dela. Ti posamezniki imajo najraje stabilno, predvidljivo delo in jih bolj zanimajo delovne razmere, manj pa njegovo bistvo. Razširitev obsega del in nalog, izzivi na delovnem mestu in drugi elementi notranje motivacije jim ne pomenijo toliko kot povišanje plače, delovne razmere in ugodnosti. V organizacijah je veliko tovrstnega dela in vsaka organizacija je zelo odvisna od uslužbencev, ki so zasidrani v varnosti in tehnično-funkcionalni sposobnostih.

\section{Podjetniška ustvarjalnost}

Nekateri že zgodaj ugotovijo, da v njih prevladuje potreba po lastnih poslih, tako da razvijajo lastne izdelke ali storitve, da s finančnimi transakcijami odpirajo nove organizacije ali pa prevzemajo že uveljavljene posle in jih preoblikujejo v skladu s svojo vizijo. Ni nujno, da so to iznajditelji ali ustvarjalni umetniki, čeprav tudi ti včasih postanejo podjetniki. Ne smemo jih tudi zamenjavati z ustvarjalnimi raziskovalci, tržnimi analitiki ali oglaševalci. Ustvarjalnà težnja $v$ tej skupini je usmerjena predvsem $\mathrm{v}$ ustanavljanje novih organizacij, ustvarjanje izdelkov ali storitev, ki se jih da identificirati s podjetnikovimi osebnimi prizadevanji, ki se bodo uveljavili in obdržali ter bodo ekonomsko uspešni. Merilo uspeha je torej ustvarjanje denarja.

Veliko posameznikov sanja o lastnem poslu in izraža te sanje na različnih stopnjah kariere. Včasih te sanje izražajo potrebo po samostojnosti. Vendar je za podjetniško zasidrane ljudi značilno, da začnejo že kmalu brezkompromisno uresničevati te

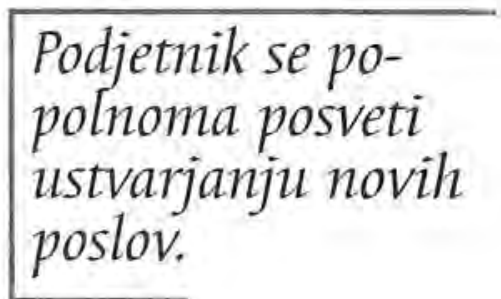
sanje; pogosto začnejo ustanavljati manjšà podjetja, ki jim prinašajo denar, že v zgodnji mladosti. Ugotovijo, da imajo ne le dar, temveč tudi izjemno motivacijo, da bi svetu dokazali, kako jim lahko uspe. Takšna motivacija velikokrat izvira iz njihove družine, $v$ kateri so bili uspešni podjetniki že $\vee$ prejšnjih generacijah. V tradicionalnih organizacijah ne ostanejo dolgo ali pa ohranijo službo kot vir postranskega zaslužka, večino svoje energije pa vložijo v lastno podjetje.

Pomembno je, da razlikujemo to karierno sidro od sidra, ki temelji na neodvisnosti in samostojnosti. Veliko posameznikov hoče imeti lastne posle zaradi potrebe po samostojnosti. Podjetniki se od njih razlikujejo po obsedenosti z dokazovanjem, da zmorejo ustvarjati posle. To velikokrat pomeni, da žrtvujejo samostojnost in stabilnost, posebej na začetnih stopnjah, preden posel zacveti. Drugi podjetniško usmerjeni posamezniki doživljajo neuspeh za neuspehom in večino svoje kariere iščejo ustvarjalne rešitve, preživljajo pa se $\mathrm{z}$ 


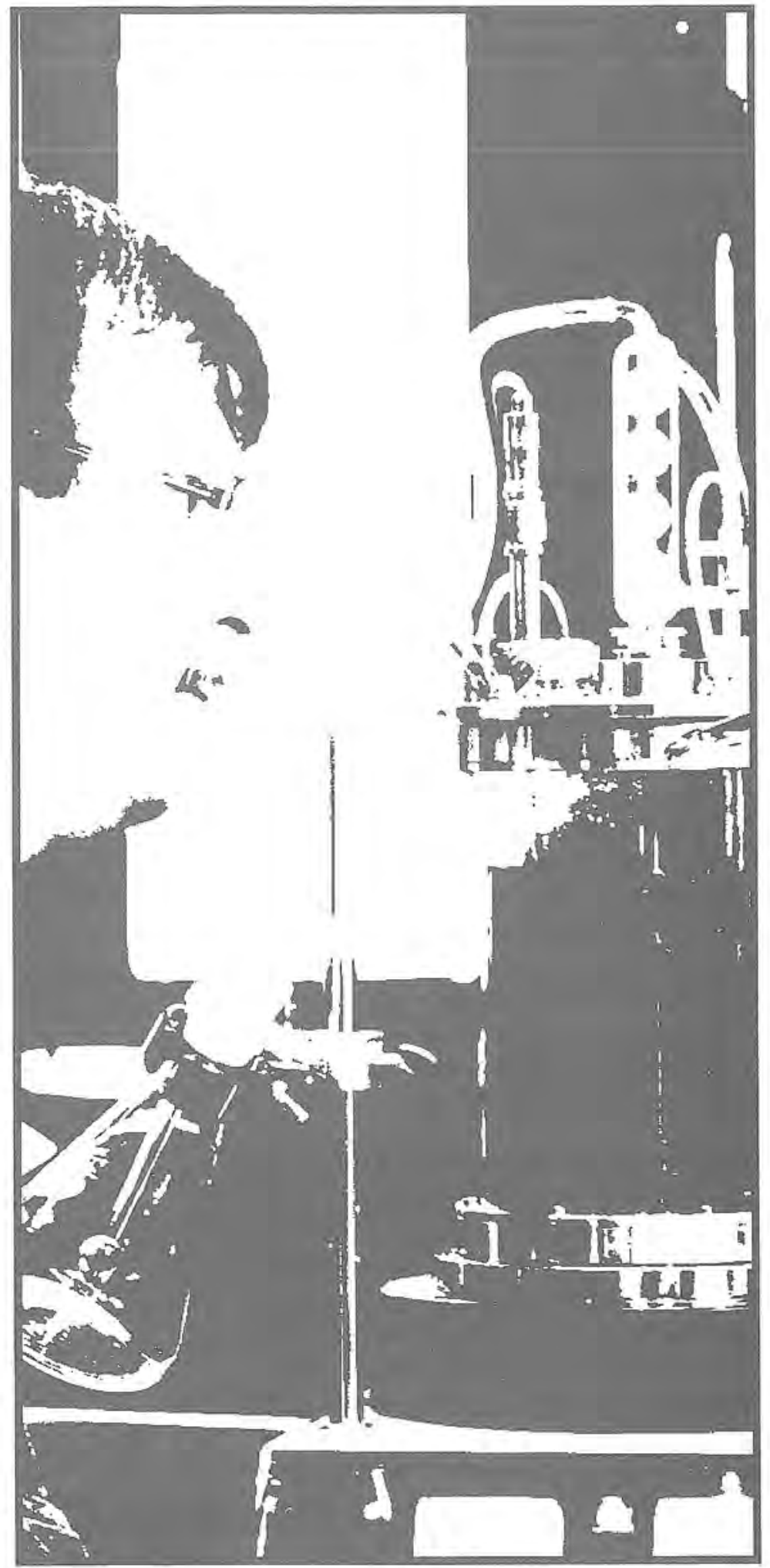

dohodki klasične službe. Recimo: nekdo je trgovski zastopnik ali vodja oddelka v podjetju, v prostem času pa skuša ustvariti nepremičninski imperij ali išče podjetje, ki bi ga lahko prevzel in vodil. »Podjetnik« je zato, ker se popolnoma posveti novemu podjetju in je pripravljen pustiti službo, takoj ko prepozna poslovno tveganje.

\section{Poslanstvo/predanost}

Nekateri ljudje se odločijo za poklic zaradi vrednot, ki jih želijo uresničiti pri svojem delu. Bolj jih zanimajo te vrednote kot njihova dejanska nadarjenost ali področja, za katera so sposobni. Njihove odločitve v zvezi s kariero temeljijo na želji, da bi tako ali drugače izboljšali svet. To karierno sidro je značilno za posameznike v poklicih, ki pomagajo drugim: zdravnike, medicinske sestre, socialne delavce, učitelje in duhovnike. Vendar je predanost značilna tudi za posameznike $\mathrm{v}$ poslovnem managementu in na organizacijskem področju. Nekaj zgledov: strokovnjakinja za kadre, ki se ukvarja s programi pozitivne diskriminacije, pravnik v podjetju, ki se zavzema za izboljšanje odnosov med zaposlenimi in vodstvom, raziskovalni znanstvenik, ki se trudi odkriti novo zdravilo, ali direktor, ki si izbere javno službo, da bi pripomogel k blaginji družbe. Vrednote, kot so delo z ljudmi, služenje človeštvu ali pomoč lastnemu narodu, so lahko močna karierna sidra.

Vendar vsakogar, ki opravlja takšen poklic, ne motivirata poslanstvo in predanost. Nekateri zdravniki, pravniki, duhovniki in socialni delavci so lahko zasidrani $\mathrm{v}$ tehnično-funkcionalni sposobnosti, samostojnosti ali varnosti, drugi pa želijo postati generalni direktorji. $\mathrm{Ne}$ da bi vedeli, katero sidro pravzaprav prevladuje pri njih, ne moremo presoditi, kaj si v resnici želijo.

Vrsta dela. Posamezniki s to vrsto kariernega sidra si želijo delo, ki jim omogoča, da 
vplivajo na organizacijo, $v$ kateri so zaposleni, ali družbeno politiko $v$ smislu njihovih vrednot. Dober zgled takega posameznika je bil profesor na agronomiji, ki je zapustil zanesljivo mesto na fakulteti in sprejel mesto vodje za okoljsko načrtovanje $\mathrm{v}$ veliki rudarski družbi. Izjavil je, da bo ostal v tem podjetju, dokler mu bodo dovolili, da vpliva na načrtovanje okolja in ima dovolj pooblastil, da bo delo dobro opravljeno.

\section{Čisti izziv}

Obstajajo tudi posamezniki, ki zasidrajo svojo kariero v predstavi, da lahko osvojijo karkoli in kogarkoli. Uspeh je zanje premagovanje nemogočih ovir, reševanje nerešljivih problemov, zmaga nad močnimi nasprotniki. Ko napredujejo, iščejo čedalje večje izzive. Za nekatere je to iskanje delovnih mest, na katerih se lotevajo vse težavnejših problemov. Vendar ti posamezniki niso tehnično-funkcionalno zasidrani, ker jim očitno ni mar, na katerem področju se pojavi problem. V ta vzorec verjetno spadajo zelo usposobljeni svetovalci za strategijo in vodenje, $\mathrm{ki} \mathrm{jih} \mathrm{vese-}$ li, če dobivajo vse težje strateške naloge.

Drugi najdejo izziv na področjih medosebnih odnosov in tekmovalnosti. Na primer: za pripadnike pomorskega letalstva je najvišji živjjenjski smisel, da se pripravljajo na končni spopad s sovražnikom (Derr, 1986), pri čemer bodo sebi in svetu dokazali premoč v boju. Morda se zdi vojaška različica tega sidra preveč zdramatizirana, toda tudi drugi posamezniki presojajo življenje $\mathrm{z}$ vidika tekmovalnosti. Trgovski potniki, poklicni športniki in celo nekateri direktorji v bistvu opisujejo svoj vsakdanjik kot bitko ali tekmovanje, pri čemer šteje le zmaga.

Vrsta dela. Večina ljudi išče določeno raven izzivoy; za posameznika, čigar karierno sidro je čisti izziv, pa je to najpomembnejše. Področje dela, vrsta podjetja, plačilni sistem, napredovanje in priznanja - vse to je podrejeno vprašanju, ali bo imel na tem delovnem mestu dovolj priložnosti, da bo preskušal svoje zmogljivosti. Če takih nenehnih preskušenj ni, se dolgočasi in postane razdražljiv. Pogosto govori o tem, kako pomembna je zanj raznolikost $v$ karieri; in prav pestrost managerskega dela in njegovi intenzivni izzivi ga včasih pritegnejo na mesto generalnega direktorja.

\section{Življenjski slog}

Na prvi pogled se zdi ta pojem kontradiktoren. Ljudje, ki pri organiziranju svoje eksistence izhajajo iz življenjskega sloga, hočejo po eni strani reči, da kariera zanje ni tako pomembna in da zato nimajo kariernega sidra. Vendar spadajo tudi ti posamezniki v okvir kariernih sider, saj vse več posameznikov, ki so močno motivirani za to, da bi imeli uspešno kariero, obenem dodaja pogoj, da mora biti ta kariera $v$ skladu z življenjskim slogom. Pri tem ne gre zgolj za uravnovešenje osebnega in poklicnega dela življenja - to se je dogajalo že v preteklosti -, temveč za to, kako povezati zadovoljevanje potreb posameznika, družine in kariere.

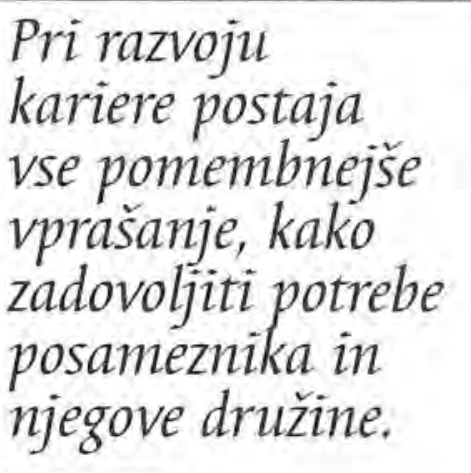

Takšno povezovanje je že samo po sebi razvijajoča se funkcija, zato posameznik postavlja na prvo mesto prožnost. V nasprotju s posamezniki, ki so zasidrani v samostojnosti, so posamezniki s sidrom življenjskega sloga pripravljeni delati $\mathrm{v}$ organizaciji, toda pod pogojem, da imajo ob pravem času na voljo prave možnosti. To so lahko potovanja ali selitev samo takrat, kadar to ustreza njihovi družini, polovični delovni čas, če to zahtevajo življenjske razmere, študijski dopust, porodniški dopust za mater in očeta, možnost dnevnega varstvá za otroke (ki postaja nujno za vse več družin, v katerih sta zaposlena oba starša) in za otroke, ki živijo 
samo z enim od staršev, gibljiv delovni čas, delo doma med običajnim delovnim časom itn. Za takšne ljudi je pomembnejši odnos podjetja kot kak poseben program; odnos, ki odseva spoštovanje do osebnih in družinskih zadev in ki omogoča pristno pogajanje o psihološki pogodbi.

Eno specifičnih področij tega kariernega sidra je vse manjša pripravljenost na selitev. $\mathrm{Na}$ začetku se je zdelo, da je to vidik sidra varnosti, vendar je postajalo vse očitnejše da posameznikom, ki se ne marajo seliti, ni toliko do varnosti in zanesljivosti, temveč je pri njih v ospredju povezovanje osebnih, družinskih in delovnih zadev.

\section{ALI OBSTAJAJO ŠE DRUGA KARIERNA SIDRA?}

Dosedanje raziskave so pokazale, da lahko večino ljudi opišemo $\mathrm{z}$ značilnostmi osmih opisanih sider. Ta sidra je moč prepoznati v najrazličnejših poklicih in veljajo za zdravnike, pravnike, učitelje, pomorske častnike, svetovalce, policijske uslužbence in celo delavce $\mathrm{v}$ proizvodnji (kadar jih opazujemo zunaj službe). Celo sneplačane« poklice,

S stališča samoanalize bi moral posameznik poskusiti ugotoviti svoje pravo sidro, obenem pa si tudi dopustiti možnost, da se njegov vzoree razlikuje od opisanih. Pomembno je, da se vse bolj zavedamo posameznikovega celostnega vzorca darov, motivov in vrednot, čeprav se popolnoma ne ujemajo za navedenimi kategorijami. Dognati mora, kaj je tisto, čemur se ne bi odrekel, če bi bil prisiljen izbirati - to je njegovo pravo karierno sidro. kot je gospodinjenje, je mogoče opazovati v luči različnih sider; žene posameznikov, ki se intenzivno posvečajo karieri, ugotavljajo, da uživajo $v$ domačem delu iz razlogov, ki odsevajo značilnosti teh sider.

Moč in ustvarjalnost se recimo zdita univerzalni potrebi in se $v$ različnih sidrnih skupi- nah izražata različno. Tehnično-funkcionalen posameznik izraža moč z velikim znanjem in spretnostmi, podjetnik z ustvarjanjem organizacije, generalni direktor s položajem, ki mu zagotavlja družbeni ugled, vpliv in sredstva, posameznik, usmerjen v poslanstvo, z moralnim prepričevanjem in tako naprej. Podobno se lahko v posamezni kategoriji posebej izrazi tudi ustvarjalnost.

Tudi raznolikost je nekaj, česar si ljudje želijo in jim pomaga $\mathrm{k}$ uspehu, vendar ni posebno sidro, saj jo je moč pridobiti s samostojnostjo, managerskimi izzivi, podjetniško dejavnostjo ali življenjskim slogom. Samo tisti, ki so zasidrani v tehnično-funkcionalni sposobnosti, varnosti in poslanstvu, zamenjajo nekatere vidike raznolikosti za druge pomembne dejavnike v razvoju kariere.

\section{ALI IMA POSAMEZNIK LAHKO VEČ KOT ENO SIDRO?}

Karierno sidro smo opredelili kot stvar, ki se je posameznik ne bi odrekel, če bi bil prisiljen izbirati. Ta opredelitev dopušča samo eno sidro - en sklop darov, vrednot in motivov, ki je na vrhu posameznikove lestvice pomembnosti. Vendar mnoge situacije v karieri omogočajo, da izpolnimo več sklopov darov, motivov in vrednot; tako izbira odpade in ne moremo ugotoviti, kaj je $\mathrm{v}$ resnici na vrhu naše prednostne lestvice. Recimo: direktor $\mathrm{v}$ podjetju, ki ima do zaposlenih očetovski, pokroviteljski odnos, lahko obenem zadovolji potrebe sider, povezanih $\mathrm{z}$ varnostjo, samostojnostjo, tehnično-funkcionalnimi sposobnostmi, vodenjem in celo Življenjskim slogom. Če hoče določiti svoje sidro, mora ugotoviti hipotetične možnosti v karieri, ki bi ga prisilile k izbiri. Ali bi bil recimo raje generalni direktor hčerinskega podjetja ali generalni izvršilni direktor? Večina posameznikov ugotovi pravo karierno sidro, če se postavi v takšno ali podobno situacijo. 


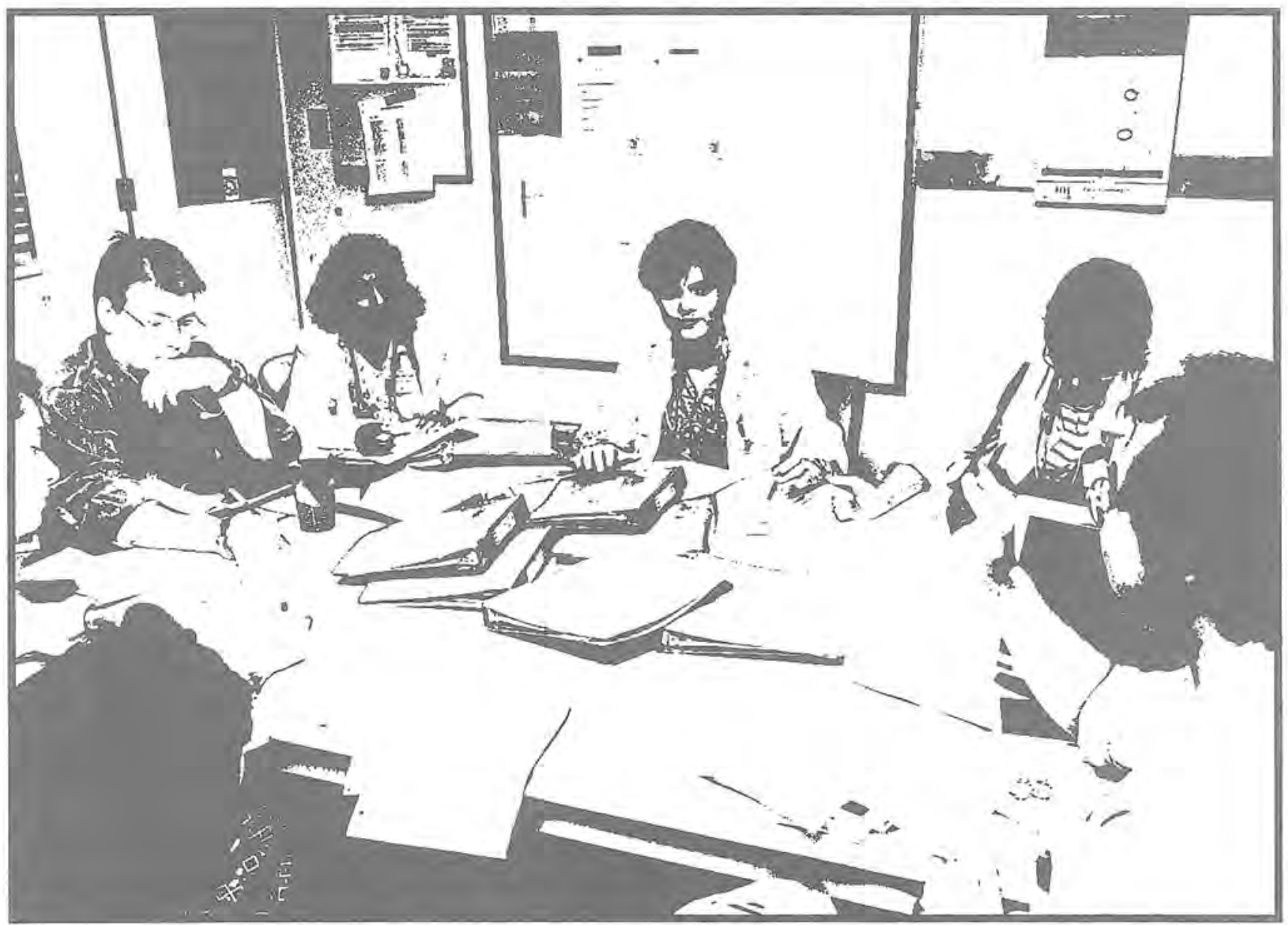

Če se jasno ne izlušči nobeno od sider, obstaja še ena možnost. Morda posameznik še nima dovolj življenjskih izkušenj, da bi razvil stališča o tem, kaj je zanj zares pomembno. Posamezniki v takšni situaciji veliko pridobijo, če določijo, katera sidra so zanje najpomembnejša, in raziščejo svoje odzive na različne situacije s sistematično izbiro delovnega mesta. Posameznik recimo ne ve, ali ima dar ali veselje za to, da bi bil generalni direktor, ker na tem področju nima priložnosti. Lahko se prostovoljno prijavi za vodenje projekta, postane predsednik komisije, vodja enote ali si pridobi potrebne izkušnje kako drugače. Ali pa poišče ljudi, ki so že na takšnem položaju, in se podrobno zanima, kakšni so njihovi občutki in izkušnje.

\section{ALI SE SIDRA SPREMINJAJO?}

Doslej raziskave še niso ponudile dovolj dokazov, ali se sidra spreminjajo ali ne.

Na podlagi petnajstletne raziskave lahko vendarle hipotetično sklenemo, da so sidra stalna. To je mogoče tudi pričakovati, kajti ko ljudje izčistijo podobo o sebi - ko se zavedajo, $v$ čem so dobri, kaj želijo in cenijo -, običajno ostanejo zvesti tej podobi. Čim bolj se poznajo, tem bolj to upoštevajo.

Posamezniki, ki v srednjih letih dramatično spremenijo kariero, skušajo uresničiti tisto, kar je bilo že ves čas njihovo sidro; preprosto nikoli niso imeli priložnosti, da bi naredili, kar so si resnično želeli. Računalniški svetovalec $\mathrm{s}$ tehnično-funkcionalnim si- 
drom, ki si je vedno želel študirati pravo, je to končno storil, potem ko si je lahko plačal študij $\mathrm{z}$ dediščino. Po diplomi je $\mathrm{v}$ manjšem mestu odprl uspešno odvetniško prakso, pri čemer je uporabljal računalniške in svetovalske spretnosti, ki si jih je pridobil že prej. Ostal je zasidran na tehnično-funkcionalnem področju (Shein, 1978).

\section{USKLAJEVANJE POTREB POSAMEZNIKA IN ORGANIZACIJE}

Posameznikovo notranjo plat kariere smo podrobno raziskovali $z$ osredotočanjem na stopnje v karieri, na to, kako lahko analiziramo razvoj kariere in uspehe, in na to, kako pojem kariernega sidra osvetljuje predstavo o sebi, ki se oblikuje med razvojem kariere. Za posameznika, ki dela kariero, je bistveno, da razvije vpogled v svoje karierno sidro, da bi bolje načrtoval kariero in sprejemal čim boljše odločitve v zvezi z njo.

Ko posamezniki dobijo vpogled v svojo kariero, ga lahko uporabijo tudi za to, da bolje vodijo kariere drugih. $Z$ drugimi besedami: osrednja tema pri razvoju kariere je, kako se potrebe posameznika ujemajo s potrebami organizacije. To je zapleteno področje, saj se posamezniki med seboj zelo razlikujejo. To kaže tudi raziskava o kariernih sidrih. Obenem pa se med seboj razlikujejo tudi organizacije. Njihove potrebe se spreminjajo, ker se spreminja okolje, v katerem delujejo. Usklajevanje dveh tako dinamičnih procesov je, milo rečeno, dokaj težavno.

Kdo naj bo odgovoren za takšno usklajevanje? Očitno mora biti to skupna odgovornost posameznikov, ki delajo kariero, organizacij z njihovimi direktorji in drugih ustanov, kot so univerze in vladne ustanove.

\section{Kaj lahko stori posameznik?}

Njegova osnovna odgovornost je, da razišče $2 / 2001$ svoje prioritete, in se o teh vpogledih pogovori $\mathrm{z}$ delodajalčevim kadrovskim direktor- jem. Če ne pozna svojih potreb in nagnjenosti, njegove kariere ni mogoče konstruktivno usmerjati. Posameznik mora jasno komunicirati z organizacijo in se razumno odločati. Nerealno je pričakovati od direktorjev in organizacij, da jih bodo dovolj dobro razumeli, da bi v njihovem imenu sprejemali dobre odločitve v zvezi s kariero (čeprav tako deluje večina kariernih sistemov). Vsakdo se namreč mora naučiti, kako naj sam usmerja lastno kariero.

\section{Kaj lahko storijo organizacije?}

Organizacije bi pri vodenju zaposlenih in skrbi za njihovo kariero morale upoštevati nekaj predlogov:

1. Ustvariti je treba prožnejše oblike kariere, sisteme za spodbujanje in nagrajevanje. Takšni sistemi lahko zadovoljijo raznolike potrebe zaposlenih, celo različnih posameznikov, zaposlenih na enakem delovnem mestu.

2. Spodbujati je treba vpogled vase in vodenje samega sebe. Vodilni ljudje v organizacijahi bi morali razčleniti svoje karierno sidro in bolj zavestno uravnavati svojo kariero, tako da bi bili zgled za podrejene.

3. Jasno je treba določiti, kaj organizacija pričakuje od posameznika, ki dela kariero. Organizacije bi morale bolje razčleniti specifične značilnosti posameznih delovnih mest in jih jasno predstaviti tistim, ki želijo narediti kariero oziroma zasesti določeno delovno mesto. Če se posameznik dobro pozna, nima pa dovolj informacij o tem, kakšne naloge bo moral opravljati na določenem delovnem mestu, se ne more pametno odločiti. Če želi organizacija postaviti posameznike na ustrezno mesto, mora jasneje opredeliti, kaj potrebuje in bolje načrtovati delovna mesta ali vloge. 


\section{Kaj lahko storijo druge ustanove in družba?}

Včasih je ujemanje med posameznikom in organizacijo $v$ nekaterih situacijah nemogoče, ker posameznikove sposobnosti ne ustrezajo povpraševanju podjetja, ker ima podjetje presežek zaposlenih ali pa se posameznik ne počuti dobro $v$ določenem tipu organizacije. Ta dilema se najpogosteje pojavi, kadar zaradi spremembe v tehnologiji veliko delavcev postane nneuporabnih火. Mnoge organizacije si prizadevajo za ponovno usposabljanje in prerazporeditev, da bi čimbolj omejile negativne učinke, toda pogostó se zgodi, da nekaterih zaposlenih ni mogoče naučiti novosti. $\mathrm{V}$ takšnih primerih mora kaka druga ustanova, ki jo podpira bodisi vlada bodisi konzorcij, poskrbeti za varnostno mrežo ali tranzicijsko rezervo, ki omogoči tem ljudem, da se na novo izobrazijo in izučijo. $\mathrm{Z}$ drugimi besedami: odpuščeni zaposleni morajo biti ekonomsko zaščiteni vsaj dve do tri leta, da se jim znova izostri žarišče kariere in si pridobijo nove spretnosti. Tehnologije se spreminjajo vse hitreje, zato bodo ustanove za premostitev sprememb v karieri čedalje pomembnejše.

Samo če organizacija, posameznik in druge ustanove sodelujejo pri izboljševanju usklajevalnega procesa ves čas kariere, je mogoče povečati delovno učinkovitost organizacij in zadovoljstvo posameznika. To je izziv za prihodnost.

\section{SKLEPNE MISLI}

Si resnično želimo, da bi bila organizacija uspešna? To bo mogoče le, če bodo v njej delali uspešni in zadovoljni posamezniki. Veliko ljudi spozna, da delo, ki ga opravljajo, ne zadovoljuje njihovih potreb oziroma jih v celoti ne zadovoljuje. S tem izgubita oba, organizacija in posameznik oziroma celotna družba. Posameznik vse bolj postaja odgovoren tudi za razvoj lastne kariere. To ga zavezuje k temu, da ugotovi in ozavesti svoje prednosti, pomanjkljivosti, sposobnosti, darove in navsezadnje tudi vrednote ter osebna prepričanja, ki ga vodijo v življenju. Prav tako se mora sprijazniti s svojimi pomanjkljivosti. Sistematičen model karirenih sider, ki smo ga predstavili v prispevku, je lahko podlaga za spoznavanje samega sebe in vrste dela, ki bi ga glede na svoje kompetence lahko opravljali najbolje. Iz Sheinove raziskave lahko sklepamo, da osem osnovnih kariernih sider, ki pravzaprav pomenijo človekov samopredstavo na podlagi izkušenj, ostaja razmeroma stabilen vzorec v življenju. V Sloveniji trenutno poteka raziskava o karirernih sidrih in načrtovanju izobraževanja (Brečko, 2001) kot prav tako pomembnemu dejayniku razvoja in načrtovanja osebne kariere. Prvi rezultati dajejo slutiti, da je tudi načrtovanje izobraževanja zelo povezano $\mathrm{z}$ opisanimi kariernimi sidri. Skupne značilnosti lahko ugotovimo glede časa, ki ga namenimo za izobraževanje, in tudi načinov, virov in pogostosti izobraževanja.

Sam koncept kariernih sider in rezultati raziskave bi bili lahko po našem mnenju skupen model za oblikovanje in načrtovanje osebne kariere, uporabni pa bi bili tudi za posameznike, delovne organizacije in poklicne svetovalce pri svetovanju tistim, ki šele vstopajo v svet dela.

\section{LITERATURA IN VIRI}

Baum, H. S. Organizational Membership. Albany, NNY: State University of New York Press, 1990.

Brečko, D. Kako se odrasli spreminjamo, Didakta, 1998. Brečko, D. Karierna sidra in načrtovanje izobraževanja (raziskava, ki poteka 2001).

Chao, G. T., O'Leary-Kelly, A., Wolfs., Klein, H. J., Gardner, P. D. „Organizational Socialization: Its Content and Consequencese, Journal of Applied Psychology, 79, 1994, str. 450-463.

Feldman, D. C. Socialization, Resocialization and Training: Reframing the Research Agenda, v: I. L. Goldstein (Ed.): Training and Development in Organizations. San Francisco: Jossey-Bass, 1989, 376-416. 
Fisher, C, D.: An Integrative Review, v: G. R. Ferris and K. M. Rowland (Eds.: Research and Personnel and Human Resources Management Greenwich, CN: JAI Press, Vol. 4, 1986, str. 101-145.

Holton, E. F. III, nNew Employee Development: A Review and Reconceptualization«. Human Resource Development Quaterly, Vol. 7, 1996.

Holton, E. F. III. Necwomer Entry into Organizational Cultures: A Neglected Performance Issue«, v: P. Dean (Ed.) Pursuing Performance Improvement, Washington, D. C.: International Society for Performance Improvement, 1998.

Katz, R. Organizational Stress and Early Socialization Experineces, v: T. A. Beehr and R. S. Bhagat (Eds.). Human Stress and Cognition in Organizations. New York: John Wiley \& Sons, 1985, str. 117-139.

McGarrell, E. J, Jr, $»$ An Orientation System that Builds Productivity«, Personnel, 60, Vol. 6, 1983, str. 32-41.

Ostroff, C, in Kozlowski, S. W. J. Organizational Socialization as a Learning Process: The Role of Information Acquisition. Personnel Psychology, Vol. 45, 1992, str. 849-874.

Premack, P. L. in Wanous, J. P. A Meta-analysis of Realistic Job Preview Experiments. Journal of Applied Psychology, Vol. 70, 1985, str. 706-719,

Shein, E. H. Career Dynamics: Matching individual and organizational needs, 1978.

Weiss, H. M. Subordinate Imitation of Supervisor Behavior: The Role of Modeling in Organizational Socialization. Organizational Behavior and Human Performance, Vol, 19, 1977, str. 89-105. 